\title{
Survival, Growth, and Body Residues of Hyalella azteca (Saussure) Exposed to Fipronil Contaminated Sediments from Non-Vegetated and Vegetated Microcosms
}

\author{
Robert Kröger · Richard E. Lizotte Jr. • \\ Matthew T. Moore
}

Received: 6 November 2008/Accepted: 24 April 2009/Published online: 8 May 2009

(C) Springer Science+Business Media, LLC 2009

\begin{abstract}
We assessed chronic effects of fipronil and metabolite contaminated sediments from non-vegetated and Thallia dealbata vegetated wetland microcosms on Hyalella azteca during wet and dry exposures. Mean sediment concentrations ( $\mathrm{ng} \mathrm{g}^{-1}$ ) ranged from 0.72-1.26, $0.01-0.69,0.07-0.23$, and $0.49-7.87$ for fipronil, fipronilsulfide, fipronil-sulfone, and fipronil-desulfinyl, respectively. No significant differences in animal survival or growth were observed between non-vegetated and vegetated microcosms during wet or dry exposures. Mean animal body residue concentrations $\left(\mathrm{ng} \mathrm{g}^{-1}\right)$ ranged from 28.4-77.6, 0-30.7, and 8.3-43.8 for fipronil, fipronil-sulfide, and fipronil-sulfone. Fipronil-desulfinyl was not detected in any animal samples.
\end{abstract}

Keywords Wetlands - Thallia dealbata.

Phenylpyrazole insecticide

Fipronil is a phenylpyrazole insecticide registered for use in the United States since 1996 to control a variety of domestic and agricultural insect pests such as mosquitos, fleas, ticks, grubs, thrips, and wireworms. According to NASS (2008), from 2001 to 2005 approximately $30,000 \mathrm{~kg} \mathrm{year}^{-1}$ of fipronil was used on agricultural crops in the US for pest management. As a result, there is a high probability for

\section{R. Kröger $(\square)$}

Department of Wildlife and Fisheries, Mississippi State

University, Box 9690, Mississippi State, MS 39762, USA

e-mail: rkroger@cfr.msstate.edu

R. E. Lizotte Jr. · M. T. Moore

USDA-ARS National Sedimentation Laboratory, Oxford, MS 38655, USA fipronil and metabolite run-off from agricultural land, entering waterways and mobilizing to sediments (Gunasekara et al. 2007) where these compounds can be moderately persistant (Lin et al. 2008). Within waterways such as drainage ditches, wetlands, or sediment retention ponds, the presence of emergent aquatic plants such as Typha latifolia L. and Thallia dealbata Fraser ex Roscoe could be useful in mitigating fipronil and metabolite contamination of water and sediment (Kröger and Moore 2008). However, due to the paucity of published data regarding fipronil and metabolite contamination, bioavailability and risk to benthic aquatic biota in waterway sediments (Gunasekara et al. 2007; Lin et al. 2008; Maul et al. 2008) the effects of fipronil and metabolite sediment contamination on sedimentassociated aquatic organisms is in need of assessment. This study assessed chronic 28-days effects of fipronil and metabolite contaminated sediments from non-vegetated and T. dealbata vegetated wetland microcosms on Hyalella azteca during wet and dry exposures. The crustacean amphipod, $H$. azteca, was used since it is an epibenthic detritivore found in association with waterway sediments throughout much of North America (de March 1981).

\section{Materials and Methods}

Two sequential experiments were conducted in April and May 2008 to assess effects of hydrological conditions (wet vs. dry) on fipronil and metabolite sediment toxicity and bioavailability between vegetated and non-vegetated microcosms. Wet conditions (April) simulated flooded field conditions, simulating dilution of fipronil amendments with standing water in drainage systems (ditches). Dry conditions (May) simulated waterless conditions in ditches prior to fipronil amendment (i.e., no dilution effect). Vegetated 
treatment consisted of six upper monospecific microcosm replicates planted in T. latifolia, followed by six lower monospecific microcosm replicates planted with $T$. dealbata connected hydrologically in series. Non-vegetated treatment consisted of two microcosm replicates devoid of vegetation, connected hydrologically in series. T. latifolia and T. dealbata are obligate wetland species commonly found in constructed wetlands and agricultural drainage ditches in Mississippi (MS) (Kröger and Moore 2008). Microcosms were half $209 \mathrm{~L}$ storage drums having an average height of $46 \pm 0.34 \mathrm{~cm}$ and an average internal diameter of $56.3 \pm 0.372 \mathrm{~cm}$. Microcosms were filled with a sand base substrate and overlaid with $5-10 \mathrm{~cm}$ of wetland soils from the University of Mississippi Field Station (UMFS), Abbeville, MS. Plant stands were grown in each microcosm for 2 years to achieve field density levels. Average total plant stem densities for $T$. latifolia and $T$. dealbata were $49 \pm 5$ $(19 \pm 5$ alive $)$ and $38 \pm 2(24 \pm 2$ alive $) \mathrm{m}^{-2}$, respectively. Fipronil (Regent $4 \mathrm{SC}^{\circledR}, 39.4 \%$ active ingredient) was amended at $5 \mu \mathrm{g} \mathrm{L}^{-1}$ per treatment replicate, representing a typical storm water run-off scenario of $0.1 \%$ of the total insecticide application for a hypothetical farm. Each treatment replicate was amended according to a calculated $6 \mathrm{~h}$ hydraulic retention time (HRT) ( $3 \mathrm{~h}$ upper and $3 \mathrm{~h}$ lower). However, the pesticide was delivered for $8 \mathrm{~h}$, to simulate overloading to the HRT for the microcosms. Surface sediment samples (top $5 \mathrm{~cm}$ ) were collected at $8 \mathrm{~h}$ from all non-vegetated $(\mathrm{n}=4)$ and $T$. dealbata vegetated microcosms $(n=6)$. However, sediment was not collected from T. latifolia vegetated microcosms due to high root density making sediment unavailable.

Fipronil and metabolites, fipronil-sulfide, fipronilsulfone, and fipronil-desulfinyl sediment and body residue concentrations were analyzed according to Bennett et al. (2000) and Smith et al. (2007), with modifications. Briefly, an Agilent Model 7890A gas chromatograph (GC), equipped with dual Agilent 7683B series autoinjectors, dual splitsplitless inlets, dual capillary columns, an Agilent ChemStation, with autoinjection set at $1.0 \mu \mathrm{L}$ injection volume. The Agilent 7890A GC was equipped with two micro electron capture detectors ( $\mu \mathrm{ECDs})$. Column oven temperatures were: initial at $75^{\circ} \mathrm{C}$ for $1 \mathrm{~min}$; ramp at $10-175^{\circ} \mathrm{C}$; hold at $175^{\circ} \mathrm{C}$ for $15 \mathrm{~min}$; ramp at $10-225^{\circ} \mathrm{C}$ and hold for $5 \mathrm{~min}$. Carrier gas used was ultra-high purity (UHP) helium at $28 \mathrm{~mL} / \mathrm{min}$ and inlet temperature at $250^{\circ} \mathrm{C}$. The $\mu \mathrm{ECD}$ temperature was $325^{\circ} \mathrm{C}$ with a constant make-up gas flow of $60 \mathrm{~mL} \mathrm{~min}{ }^{-1}$ UHP nitrogen. Detection limits for sediment samples were $0.1 \mathrm{ng} \mathrm{g}^{-1}$ and for animal tissue samples were $1 \mathrm{ng} \mathrm{g}^{-1}$. Recoveries of fortified samples were $\geq 90 \%$ for all analytes.

Twenty-eight day static non-renewal bulk sediment bioassays were conducted according to modified USEPA (1994) protocol as follows. Briefly, exposures consisted of
$40 \mathrm{~g}$ wet weight sediment sample with $160 \mathrm{~mL}$ overlying hardness adjusted water (free from priority pollutants) from the UMFS (Deaver and Rodgers 1996) placed in four replicate exposure chambers $(250 \mathrm{~mL}$ borosilicate glass beakers) per treatment replicate along with two, $6 \mathrm{~mm}$ diameter maple leaf discs as substrate and food. Control sediment was also obtained from the UMFS. Six 4-5-days old H. azteca were placed in each exposure chamber. Animals were fed $0.1,0.5,0.5,0.5 \mathrm{~mL}$ of a $1: 1$ suspension mixture of rabbit chow:Tetramin ${ }^{\circledR}$ flake food at 2, 2, 4, $10 \mathrm{~g} \mathrm{~L}^{-1}$ every 2 days during week 1, 2, 3, and 4, respectively. Exposure chambers were aerated every other day and water levels were maintained by addition of UMFS water to replace evaporated water. Bioassays were conducted in a Powers Scientific, Inc. Animal Growth Chamber with a 16:8 h (light:dark) photoperiod and a set temperature of $23 \pm 1{ }^{\circ} \mathrm{C}$. Standard physical and chemical water characteristics for sediment tests (temperature, $\mathrm{pH}$, dissolved oxygen, conductivity, hardness, alkalinity, ammonium- $\mathrm{N}$, nitrate- $\mathrm{N}$, and nitrite-N) were measured according to APHA (1998). Bioassay endpoints measured were survival and growth (as wet weight in milligram).

Data were analyzed using SigmaStat ${ }^{\circledR}$ v.2.03 statistical software (SPSS 1997) and included descriptive statistics and one-way analysis of variance (ANOVA) with Tukey's multiple-range test, when appropriate. Statistical analyses were conducted on sediment pesticide and metabolite concentrations, bioassay endpoints of survival and growth (as wet weight), and pesticide and metabolite body residue concentrations. When data failed parametric assumptions, a Kruskal-Wallis one-way ANOVA on ranks with Dunn's multiple-range test was utilized. Alpha was set at 0.05 .

\section{Results and Discussion}

UMFS control sediments were characterized as loamy sand ( $88.4 \%$ sand, $11.5 \%$ silt, $0.1 \%$ clay) with low total organic carbon (OC) content $(0.3 \%)$. Non-vegetated sediments were a silt loam ( $48.1 \%$ sand, $51.8 \%$ silt, $0.1 \%$ clay) with $1.8 \%-3.1 \%$ OC. T. dealbata vegetated sediments were a sandy loam $(54.6 \%$ sand, $45.3 \%$ silt, $0.1 \%$ clay) with $3.2 \%-5.0 \%$ OC. Mean $8 \mathrm{~h}$ sediment concentrations $\left(\mathrm{ng} \mathrm{g}^{-1}\right)$ ranged from $0.72-1.26,0.01-0.69,0.07-0.23$, and 0.49-7.87 for fipronil, fipronil-sulfide, fipronil-sulfone, and fipronil-desulfinyl, respectively (Table 1). Patterns of fipronil, fipronil-sulfide, and fipronil-sulfone contamination in sediments were similar for both non-vegetated and vegetated microcosms under both wet and dry exposures. Only fipronil-desulfinyl had significantly different levels of contamination between non-vegetated and vegetated microcosms during dry exposure (Table 1). Observed sediment concentrations of fipronil and fipronil-sulfone in 
Table 1 Mean (SD) fipronil and metabolite sediment concentrations $\left(\mathrm{ng} \mathrm{g}^{-1} \mathrm{~d} / \mathrm{w}\right.$; TR, trace) in non-vegetated and Thallia dealbata vegetated microcosms during wet and dry exposures

\begin{tabular}{lll}
\hline Exposure & Non-vegetated & T. dealbata vegetated \\
\hline Wet & & \\
$\quad$ Fipronil & $0.8(0.1)$ & $0.7(0.2)$ \\
$\quad$ Fipronil-sulfide & TR & $0.1(0.1)$ \\
$\quad$ Fipronil-sulfone & $0.1(0.2)$ & $0.2(0.2)$ \\
$\quad$ Fipronil-desulfinyl & $0.5(1.0)$ & $2.3(3.2)$ \\
Dry & & \\
Fipronil & $1.3(0.7)$ & $1.0(0.4)$ \\
Fipronil-sulfide & $0.7(0.9)$ & $0.2(0.1)$ \\
Fipronil-sulfone & $0.1(0.1)$ & $0.1(0.1)$ \\
Fipronil-desulfinyl & $7.9(5.8)^{\dagger}$ & $2.0(1.9)^{\dagger}$ \\
\hline
\end{tabular}

$\dagger$ Statistically significantly different $(p<0.05)$ non-vegetated versus vegetated

the current study were comparable to sediment concentrations for these same compounds occurring in waterways, such as oxbow lakes and bayous, within the intensively cultivated region of the lower Mississippi River alluvial plain (i.e., the Delta) where median concentrations (ng g $\mathrm{g}^{-1}$ d/w) ranged from $<0.1$ to 1.2 and $<0.1$ to 4.1 for fipronil and fipronil-sulfone, respectively (Knight et al. 2007). Sediment concentrations $\left(\mathrm{ng} \mathrm{g}^{-1}\right)$ of the metabolites fipronil-sulfide and fipronil-desulfinyl ranged from 0.6 to 24.8 and 0.5 to 7.0 , respectively, in samples from the Mermentau River, Louisiana, draining a watershed with significant agricultural land use (Gunasekara et al. 2007).

Mean standard overlying water quality parameters assessed during all sediment bioassays were within accepted limits for hardness adjusted water (Table 2) according to US EPA methods using H. azteca (USEPA 1994). No significant differences in 28-days animal survival or growth were observed among control, non-vegetated and vegetated microcosms during wet or dry sediment exposures. Mean 28-days $H$. azteca survival in control sediments was $87.2 \% \pm 9.3 \%$. Treatment survival ranged from 83.8 to 87.5 in non-vegetated sediments and $70.8 \%$ to $88.2 \%$ in vegetated sediments (Table 3). Mean 28-days animal wet body weight (growth) in control sediments was $2.4 \pm 0.1 \mathrm{mg}(\mathrm{w} / \mathrm{w})$. Treatment growth ranged from 2.0 to $2.3 \mathrm{mg}$ in non-vegetated sediments and 2.2 to $2.3 \mathrm{mg}$ in vegetated sediments (Table 3 ).

Available published data on sediment-bound fipronil and metabolites fipronil-sulfone and fipronil-sulfide toxicity are limited to the Dipteran insect, Chironomus dilutus (formerly tentans) (Maul et al. 2008). There is no available published data for the sediment toxicity of fipronil-desulfinyl or any of these compounds with the amphipod, H. azteca. Maul et al. (2008) showed C. dilutus sediment 10-days LC50 values were $0.13,0.16$, and $0.12 \mu \mathrm{g} \mathrm{g}^{-1}$ OC
Table 2 Mean (SD) overlying water quality parameters for 28-days Hyalella azteca sediment toxicity tests using sediment from nonvegetated and Thallia dealbata vegetated microcosms during wet and dry exposures

\begin{tabular}{lcc}
\hline Exposure & $\begin{array}{l}\text { Non- } \\
\text { vegetated }\end{array}$ & $\begin{array}{l}\text { T. delabata } \\
\text { vegetated }\end{array}$ \\
\hline Wet & & \\
Temperature $\left({ }^{\circ} \mathrm{C}\right)$ & $23.0(0.0)$ & $23.1(0.0)$ \\
$\mathrm{pH}$ & $7.3(0.1)$ & $7.2(0.1)$ \\
Dissolved oxygen $\left(\mathrm{mg} \mathrm{L}^{-1}\right)$ & $6.0(0.4)$ & $5.8(0.5)$ \\
Alkalinity $\left(\mathrm{mg} \mathrm{L}^{-1}\right.$ as & $44.9(4.3)$ & $49.9(6.4)$ \\
$\left.\mathrm{CaCO}_{3}\right)$ & & \\
Hardness $\left(\mathrm{mg} \mathrm{L}^{-1}\right.$ as $\left.\mathrm{CaCO}_{3}\right)$ & $62.0(4.3)$ & $61.3(6.4)$ \\
Conductivity $\left(\mu \mathrm{mhos} \mathrm{cm}{ }^{-1}\right)$ & $252.3(9.8)$ & $258.3(15.2)$ \\
Nitrite-N $\left(\mu \mathrm{g} \mathrm{L}^{-1}\right)$ & $26.8(14.6)$ & $24.5(11.7)$ \\
Ammonia-N $\left(\mu \mathrm{g} \mathrm{L}^{-1}\right)$ & $48.9(30.9)$ & $35.3(34.9)$ \\
Nitrate-N $\left(\mu \mathrm{g} \mathrm{L}^{-1}\right)$ & $244.3(101.5)$ & $188.2(84.8)$ \\
Dry & & \\
Temperature $\left({ }^{\circ} \mathrm{C}\right)$ & $23.1(0.0)$ & $23.1(0.0)$ \\
pH & $7.3(0.1)$ & $6.9(0.2)$ \\
Dissolved oxygen $\left(\mathrm{mg} \mathrm{L}^{-1}\right)$ & $6.2(0.0)$ & $5.8(0.4)$ \\
Alkalinity $\left(\mathrm{mg} \mathrm{L}^{-1}\right.$ as & $44.9(4.3)$ & $41.3(3.5)$ \\
CaCO & & \\
Hardness $\left(\mathrm{mg} \mathrm{L}^{-1}\right.$ as $\left.\mathrm{CaCO}_{3}\right)$ & $55.6(8.5)$ & $57.0(4.4)$ \\
Conductivity $\left(\mu \mathrm{mhos} \mathrm{cm}{ }^{-1}\right)$ & $264.8(8.4)$ & $242.5(8.5)$ \\
Nitrite-N $\left(\mu \mathrm{g} \mathrm{L}^{-1}\right)$ & $25.4(5.1)$ & $48.8(46.2)$ \\
Ammonia-N $\left(\mu \mathrm{g} \mathrm{L}^{-1}\right)$ & $27.1(21.8)$ & $29.7(30.5)$ \\
Nitrate-N $\left(\mu \mathrm{g} \mathrm{L}^{-1}\right)$ & $162.5(51.0)$ & $332.3(341.9)$ \\
\hline & &
\end{tabular}

Table 3 Mean (SD) 28-days Hyalella azteca survival (\%) and growth $(\mathrm{mg} \mathrm{w} / \mathrm{w})$ after exposure to fipronil contaminated sediments from non-vegetated and Thallia dealbata vegetated microcosms during wet and dry exposures

\begin{tabular}{lcc}
\hline Exposure & Non-vegetated & T. dealbata vegetated \\
\hline Wet & & \\
$\quad$ Survival (\%) & $83.3(11.3)$ & $70.8(27.9)$ \\
$\quad$ Growth (mg wet weight) & $2.0(0.3)$ & $2.3(0.6)$ \\
Dry & & \\
$\quad$ Survival (\%) & $87.5(5.9)$ & $88.2(11.3)$ \\
$\quad$ Growth (mg wet weight) & $2.3(0.8)$ & $2.2(0.7)$ \\
\hline
\end{tabular}

for fipronil, fipronil-sulfide, and fipronil-sulfone, respectively. Sediment fipronil and fipronil-sulfide concentrations in the present study, adjusted for OC, are below reported 10-days LC50 values for $C$. dilutus, and these concentrations did not affect $H$. azteca survival and growth after 28-days exposures. Gunasekara et al. (2007) showed insects to be much more sensitive to fipronil and metabolites than crustaceans in aqueous exposures. As a result, sediment fipronil and metabolite concentrations may need 
to be greater than those examined by Maul et al. (2008) to elicit responses from the crustacean $H$. azteca.

Mean animal body residue concentrations ( $\mathrm{ng} \mathrm{g}^{-1}$ ) ranged from 28.4-77.6, 0-30.7, and 8.3-43.8 for fipronil, fipronil-sulfide, and fipronil-sulfone. Fipronil-desulfinyl was not detected in any animal samples (Table 4). Fipronil-sulfide body residue concentrations were significantly greater with $T$. dealbata vegetated sediments than non-vegetated sediments during wet exposures. However, fipronil-sulfone body residue concentrations were significantly greater during dry exposures than wet exposures only within non-vegetated sediments (Table 4). Patterns of fipronil metabolite body residues show the influence of vegetation and facultative conditions on bioavailability of these compounds to H. azteca.

Few studies have examined the bioavailability of fipronil in crustaceans (Chaton et al. 2002; Biever et al. 2003; Smith et al. 2007) and only Smith et al. (2007) assessed any fipronil metabolites (fipronil-sulfone). These previous studies showed a broad spectrum of fipronil concentrations in crustacean tissues. Biever et al. (2003) observed $<5 \mathrm{ng} \mathrm{g}^{-1}$ fipronil residues in tail muscle of crayfish (Procambarus clarkia). Smith et al. (2007) showed fipronil and fipronilsulfone body residues ranging from $<1$ to 5 and 14 to $201 \mathrm{ng} \mathrm{g}^{-1}$, respectively in $H$. azteca. Chaton et al. (2002) noted that crustaceans appear to be able to accumulate large amounts of fipronil, regardless of their sensitivity to the compound and suggested that crustaceans may either be resistant to the compound's mode of action, able to detoxify the compound, or accumulate the compound in body fat or cuticle. In the current study, fipronil body residues as great

Table 4 Mean (SD) fipronil and metabolite 28-days Hyalella azteca body residue concentrations $\left(\mathrm{ng} \mathrm{g}^{-1} \mathrm{w} / \mathrm{w}\right.$; ND, not detected; TR, trace) exposed to fipronil contaminated sediments from non-vegetated and Thallia dealbata vegetated microcosms during wet and dry exposures

\begin{tabular}{lll}
\hline Exposure & Non-vegetated & T. dealbata vegetated \\
\hline Wet & & \\
$\quad$ Fipronil & $28(30)$ & $47(31)$ \\
Fipronil-sulfide & $1(2)^{\dagger}$ & $31(19)^{\dagger}$ \\
Fipronil-sulfone & $8(4)^{*}$ & $12(6)$ \\
Desulfinylfipronil & $\mathrm{ND}$ & $\mathrm{ND}$ \\
Dry & & \\
Fipronil & $74(40)$ & $78(53)$ \\
Fipronil-sulfide & $\mathrm{TR}$ & $7(18)$ \\
Fipronil-sulfone & $44(14)^{*}$ & $29(31)$ \\
Desulfinylfipronil & $\mathrm{ND}$ & $\mathrm{ND}$
\end{tabular}

\footnotetext{
${ }^{\dagger}$ Statistically significantly different $(p<0.05)$ non-vegetated versus vegetated

* Statistically significantly different $(p<0.05)$ wet versus dry
}

as $78 \mathrm{ng} \mathrm{g}^{-1}$ elicited no observed survival or growth effects for $H$. azteca. Observed differences in uptake of fipronilsulfide and fipronil-sulfone under different vegetated or facultative conditions may be associated with differences in OC amounts (as a possible additional nutritive food source) and changes in sediment chemistry when the microcosms shifted from wet to dry facultative conditions.

Results of the present study showed patterns of fipronil and metabolite contamination in sediments were similar for both non-vegetated and vegetated microcosms under both wet and dry exposures with the exception of fipronildesulfinyl. Animals did not show any significant survival or growth impairment at the greatest observed pesticide and metabolite concentrations. However, with the exception of fipronil-desulfinyl, these compounds were bioavailable and had varying body residue patterns under differing vegetated and facultative conditions.

Acknowledgments Appreciation is extended to J. Renee Russell, Lisa Brooks, Dan McChesney, and Sam Testa for sample collection and analytical assistance. Mention of equipment, software or a pesticide does not constitute an endorsement for use by the US Department of Agriculture nor does it imply pesticide registration under FIFRA as amended. All programs and services of the USDA are offered on a nondiscriminatory basis without regard to race, color, national origin, religion, sex, marital status, or handicap.

\section{References}

American Public Health Association (APHA) (1998) Standard methods for the examination of water and wastewater, 20th edn. American Public Health Association, Washington, DC

Bennett ER, Moore MT, Cooper CM, Smith S (2000) Method for the simultaneous extraction and analysis of two current use pesticides, atrazine and lambda-cyhalothrin, in sediment and aquatic plants. Bull Environ Contam Toxicol 64:825-833. doi:10.1007/ s001280000077

Biever RC, Hoberg JR, Jacobsen B, Dionne E, Sulaiman M, McCahon P (2003) $\mathrm{ICON}^{\circledR}$ rice seed treatment toxicity to crayfish (Procambarus clarkii) in experimental rice paddies. Environ Toxicol Chem 22:167-174. doi:10.1897/1551-5028 (2003)022<0167:IRSTTT $>2.0$. CO;2

Chaton PF, Ravanel P, Tissut M, Meyran JC (2002) Toxicity and bioaccumulation of fipronil in the nontarget arthropodan fauna associated with subalpine mosquito breeding sites. Ecotox Environ Saf 52:8-12. doi:10.1006/eesa.2002.2166

Deaver E, Rodgers JH Jr (1996) Measuring bioavailable copper using anodic stripping voltammetry. Environ Toxicol Chem 15:19251930. doi:10.1897/1551-5028(1996)015<1925:MBCUAS $>2.3$. $\mathrm{CO} ; 2$

de March BGE (1981) Hyalella azteca (Saussure). In: Lawrence SG (ed) Manual for the culture of selected freshwater invertebrates. Can Spec Publ Fish Aquat Sci 54:61-77

Gunasekara AS, Truong T, Goh KS, Spurlock F, Tjeerdema RS (2007) Environmental fate and toxicology of fipronil. J Pest Sci 32:189-199. doi:10.1584/jpestics.R07-02

Knight SS, Lizotte RE Jr, Smith S Jr, Bryant CT (2007) Distribution and spatial variation in surface sediment pesticides of Mississippi alluvial plain. J Int Environmental Application \& Science 2:40-50 
Kröger R, Moore MT (2008) Utilization of common ditch vegetation in the reduction of fipronil and its sulfone metabolite. Pest Manag Sci. doi:10.1002/ps.1619

Lin K, Haver D, Oki L, Gan J (2008) Transformation and sorption of fipronil in urban stream sediments. J Agric Food Chem. doi: $10.1021 / \mathrm{jf} 8018886$

Maul JD, Brennan AA, Harwood AD, Lydy MJ (2008) Effect of sediment associated pyrethroids, fipronil, and metabolites on Chironomus tentans growth rate, body mass, condition index, immobilization, and survival. Environ Toxicol Chem. doi: 10.1897/08-185.1

Smith S, Lizotte RE, Knight SS (2007) Pesticide body residues of Hyalella azteca exposed to Mississippi delta sediments. Bull
Environ Contam Toxicol 78:26-29. doi:10.1007/s00128-0079020-2

Statistical Package for the Social Sciences (SPSS), Inc. (1997) SigmaStat for windows version 2.03. SPSS, Chicago

US Department of Agriculture (USDA) National Agricultural Statistical Service (NASS) (2008) Agricultural chemical use database. http://www.pestmanagment.info/nass/

US Environmental Protection Agency (USEPA) (1994) Methods for measuring the toxicity and bioaccumulation of sediment-associated contaminants with freshwater invertebrates. EPA 600/R-94/ 024. US Environmental Protection Agency, Washington, DC 